ISSN 1392-3196 / e-ISSN 2335-8947

Zemdirbyste-Agriculture, vol. 100, No. 4 (2013), p. 369-376

DOI 10.13080/z-a.2013.100.047

\title{
Impact of climate variability in Lithuania and Belarus on atmospheric precipitation infiltration: lysimetric study
}

\author{
Liudmila TRIPOLSKAJA ${ }^{1}$, Galina PIROGOVSKAJA ${ }^{2}$ \\ ${ }^{1}$ Voke Branch of the Lithuanian Research Centre for Agriculture and Forestry \\ Žalioji 2, Traku Voké, Vilnius, Lithuania \\ E-mail: liudmila.tripolskaja@voke.lzi.lt \\ ${ }^{2}$ Belarus Institute of Soil Science and Agrochemistry \\ 62 Kazinets, Minsk, Belarus \\ E-mail: brissa_pir@mail.ru
}

\begin{abstract}
The average annual rate of atmospheric precipitation is about $38-40 \%$ on the territories of the Republics of Lithuania and Belarus. On agricultural land, with runoff waters various chemical elements leach into the subsoil and cause negative impact on the quality of water bodies. The main objectives of this study were to assess the influence of climate variability on the infiltration of atmospheric precipitation in Lithuania (Vilnius) and Belarus (Minsk). The long-term lysimetric experiment (lysimeter surface area of $1.75-2.0 \mathrm{~m}^{2}$ ) data of the precipitation infiltration during 1987-2008 was used in the study.

It was determined that in 1987-2007 precipitation amount on the studied territory in Lithuania (Vilnius) slightly increased $(+10 \mathrm{~mm})$ compared with the climate norm, while in Belarus it significantly decreased $(-109 \mathrm{~mm})$, precipitation amount in separate months changed, and it had an impact on the amount of precipitation infiltration. In Lithuania, strong correlation between the amounts of precipitation and infiltrated water was established during the summer period $\left(R^{2}=0.77, \mathrm{t}_{\mathrm{r}}=99.9 \%\right)$, moderate correlation - in autumn $\left(R^{2}=0.48, \mathrm{t}_{\mathrm{r}}=99.9 \%\right)$. In Belarus, a strong correlation was established in spring $\left(R^{2}=0.978, \mathrm{t}_{\mathrm{r}}=99.9 \%\right)$, moderate correlation - in summer $\left(R^{2}=0.537\right.$, $\mathrm{t}=99.9 \%)$, and winter $\left(R^{2}=0.592, \mathrm{t}=99.9 \%\right)$ periods. During 1987-2008 in Lithuania a significant increase $(p<0.05)$ in infiltration of atmospheric precipitation in the course of the spring period was established. The trend of increased infiltration in summer and reduced infiltration during the autumn period is also established (correlation is insignificant). In Belarus (Minsk), due to lower amount of atmospheric precipitation in 1987-2007, the infiltration decreased during all seasons of the year, but because of the variation of the climatic conditions, no statistically significant trends $(p>0.05)$ of change in infiltration were established.
\end{abstract}

Key words: climate, lysimeters, rainfall infiltration, year seasons.

\section{Introduction}

Percolative soil moisture regime is characteristic of many Western and Eastern European countries, and percolation of precipitation significantly affects chemical composition of groundwater and river run-off. In natural ecosystems, the amount of leached materials depends on natural factors: parent material, soil texture, vegetation, moisture and temperature regimes, etc. However, in every country agricultural land occupies part of the territory, where the range of agrotechnical measures are used to increase crop yields; these measures could increase the amount of leached chemical elements and therefore adversely affect the quality of groundwater basins and reservoirs (Schoumans, Groenendijk, 2000; Kutra et al., 2006, Baigys, 2009; Strusevičius et al., 2009; Adomaitis et al., 2010).

Precipitation infiltration is closely associated with hydrothermal regime - precipitation amount and air temperature, which during the last two decades in Belarus and Lithuania are characterized by various major deviations from the climatic normal. After analysis of air temperature and precipitation changes in 100 years' time, Lithuanian climatologists conclude that the average annual temperature has increased by $0.1-0.9^{\circ} \mathrm{C}$. Temperature of the second half of winter and spring period significantly increased $\left(1.1-1.7^{\circ} \mathrm{C}\right)$, while the average autumn temperature decreased by $0.3^{\circ} \mathrm{C}$. The number of days with freezing temperatures also decreased. Precipitation amount has changed unequally in different parts of the country, but one can see the trend of declining precipitation during warm and increasing during cold seasons (Bukantis et al., 2001; Galvonaite, Valiukas, 2005). Analysis of meteorological data of the period 1881-2007 in Belarus revealed that short-term periods of warming interchanged with colder periods of similar duration. A substantial increase in temperature was recorded in the winter of 1989 and repeatedly in 2000 and 2007. The apparent warming period has been continuing until now (Климат Беларуси, 1996, Логинов, 2008). 
In Central Europe, the average temperature has increased by 1.1 to $1.3{ }^{\circ} \mathrm{C}$ in 100 years (Kutilek, Nielsen, 2010).

The mentioned climatic changes affect soil hydrological regime, and, what is most important in case of percolative soil moisture regime, precipitation infiltration intensity. The use of global circulation models ECHAM4 and GDFL-R30 as well as the hydrological river model WatBal (the conception of the model was originally developed by Kaczmarek, 1993) for the calculation of the Lithuanian river basin runoff allows prediction that during the $21^{\text {st }}$ century annual river runoff will increase, spring floods will decline and they will shift toward the beginning of the year (Kilkus et al., 2006). With increased infiltration we can expect more intensive leaching of chemical elements from agricultural land and, consequently, higher nutrient concentrations in groundwater and other water bodies.

The aim of this work was to assess the impact of changing climatic conditions on precipitation infiltration on the territories of eastern Lithuania and western Belarus employing the 1987-2008 data of lysimetric studies on precipitation infiltration.

\section{Materials and methods}

For comparison of the impact of climate change on precipitation infiltration, the data obtained in stationary lysimetric facility sites in Lithuania (Voke Branch, Lithuanian Institute of Agriculture, Vilnius; $54^{\circ} 37^{\prime} \mathrm{N}, 25^{\circ} 08^{\prime} \mathrm{E}$ ) and Belarus (Belarus Institute of Soil Science and Agrochemistry, Minsk; 53 $51^{\prime} \mathrm{N}, 27^{\circ} 30^{\prime} \mathrm{E}$ ) separated by $200 \mathrm{~km}$ in south-east direction was used. Meissner et al. (2006) claim, that only lysimeters permit a direct determination of the amount of water percolating through a soil profile and of the type and amount of solutes contained in it.

The lysimetric data of the precipitation infiltration during March 1987 - February 2008 was used in the study. At Vokè Branch, lysimetric equipment consisted of a cylindrical concrete structure with a surface area of $1.75 \mathrm{~m}^{2}$; the test soil layer was $0.60 \mathrm{~m}$ (corresponding to the drainage depth). The lysimeters were filled with soil typical of Southeastern Lithuania - sandy loam Luvisol (according to the FAO-UNESCO classification - Haplic Luvisol, LVh). At the Belarus Institute of Soil Science and Agrochemistry, lysimeters of the same construction were installed; their surface area was $2.0 \mathrm{~m}^{2}$ and the test soil layer was $1.5 \mathrm{~m}$. The lysimeters were also filled with sandy loam Luvisol. The study showed that under sandy soil conditions no significant differences occurred between the measurements from drainage lysimeter types (Meissner et al., 2010).

During the research period, various agricultural crops (cereals, row crops, annual grass and legume mixtures) were cultivated in lysimeters according to the common agricultural practices. In order to avoid the impact of the applied agrochemical measures on the precipitation infiltration, only data from the control treatment with only traditional agro-technical measures used were selected into the database (the number of treatment replications - three). Filtrate volume $\left(1 \mathrm{~m}^{2}\right)$ was calculated for each month, season and year. The precipitation amount was calculated according to the data of Vilnius Meteorological Station, which is located $0.2 \mathrm{~km}$ away from the lysimetric facility site. In Belarus, precipitation amount was calculated according to the data of meteorological station situated on the territory of lysimetric facility site.

Method for assessment of precipitation amount and infiltration by the seasons of a year. Research data grouping corresponds to a calendar-year seasons: spring $-3^{\text {rd }}-5^{\text {th }}$ months, summer $-6^{\text {th }}-8^{\text {th }}$ months, autumn $9^{\text {th }}-11^{\text {th }}$ months, winter $-12^{\text {th }}-2^{\text {nd }}$ months. Amounts of precipitation and infiltration for the winter period were calculated by summing up precipitation or filtrate volumes in December of a certain year (n) and January and February of the following year $(n+1)$. Such records are associated with the air temperature regime, because at a negative air temperature solid precipitation falls, which passes into the liquid phase only at positive temperature and; therefore, its infiltration can take place much later after it falls.

Assessment of the changes in rainfall infiltration. In order to evaluate the changes in the rate of precipitation infiltration ( $1 \mathrm{~m}^{2}$ and $\%$ of the rainfall amount) the average of the total observation period (March 1987 - February 2008) was calculated; it was compared with the averages of the first 5-year period (1987-1991) and the last 5-year period (2003-2008). The data was processed using the correlation regression analysis with $A N O V A$.

\section{Results and discussion}

Precipitation. The average annual precipitation (climate normal 1961-1990) of Lithuanian is $675 \mathrm{~mm}$, while in Vilnius it is $664 \mathrm{~mm}$ (Galvonaite et al., 2007). During 1987-2007 the annual precipitation amount in Vilnius varied from $494 \mathrm{~mm}$ in 1991 up to $830 \mathrm{~mm}$ in 1993; it diverged from the climate normal by $-34.4 \%$ up to $+25.0 \%$. Compared to the period before the year 2000, during the last decade the divergences were lower (Fig. 1). But their annual volume, compared with the climate normal (1961-1990), increased by an average of $13 \mathrm{~mm}$ during 1987-2007.

On the territory of Belarus, which is located southeast of Lithuania and is further from the impact of the Baltic Sea, the precipitation climate normal is slightly higher than in Lithuania and reaches $696 \mathrm{~mm}$ (Климат Беларуси, 1996). During the analyzed period, rainfall amount varied over a wide range from $462.8 \mathrm{~mm}$ in 1995 up to $767.5 \mathrm{~mm}$ in 1998. Deviation ranged from $-33.5 \%$ to $+10.3 \%$. However, unlike in Lithuania, over the last two decades (1987-2007) annual precipitation in Belarus decreased substantially (by $109 \mathrm{~mm}$ ) compared with the climate normal. If during 1961-1990 the annual precipitation amount in both countries differed by only $28 \mathrm{~mm}$, in 1987-2007 the difference increased to $87 \mathrm{~mm}$. Significant precipitation decline on the territory of Belarus could have changed the precipitation infiltration intensity, reduce leaching of chemical elements into groundwater, runoff into rivers, but it could have a negative impact on crop yields. Precipitation amount differs over separate periods of the year and this together with the air temperature predetermines the infiltration volume. 


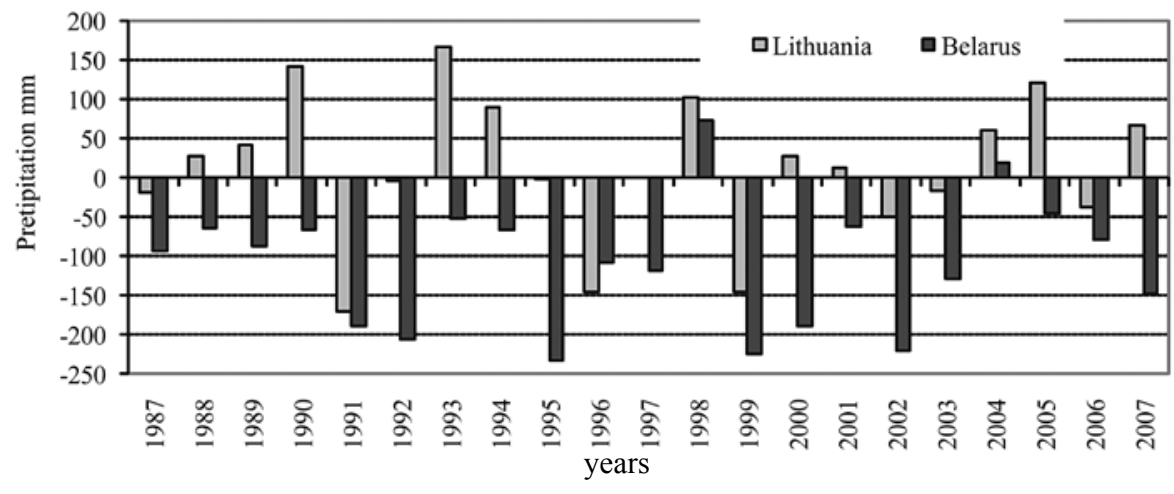

Data of Vilnius Meteorological Station and Meteorological Station of Belarus Institute of Soil Science and Agrochemistry

Figure 1. Deviation of rainfall amount from the climate normal in Lithuania and Belarus during 1987-2007

In eastern Lithuania, the precipitation amount in summer (34.6\% of the annual amount) is higher than in winter $(18.1 \%)$ (Table 1). Such distribution of precipitation is favourable for the development and yielding of agricultural plants, it also reduces the infiltration in soil because in summer the evaporation is enhanced and soil is covered with vegetation. On the territory of Belarus, the precipitation distribution throughout the year is similar, only slightly more precipitation $(1.9 \%)$ is recorded in summer and less (2.7\%) in autumn. During 1987-2007 the precipitation distribution in the course of the year did not substantially differ from the climate normal; during spring and autumn periods the decline in precipitation amount made $0.7-1.8 \%$, while in winter period $2.6 \%$ increase was recorded.

Table 1. Precipitation amount and distribution by seasons of a year in Lithuania and Belarus

\begin{tabular}{|c|c|c|c|c|c|c|c|c|}
\hline \multirow{3}{*}{ Season } & \multicolumn{4}{|c|}{ Lithuania (Vilnius) } & \multicolumn{4}{|c|}{ Belarus (Minsk) } \\
\hline & \multicolumn{2}{|c|}{$\begin{array}{c}\text { climate normal } \\
1961-1990\end{array}$} & \multicolumn{2}{|c|}{$\begin{array}{c}\text { mean of } \\
1987-2007\end{array}$} & \multicolumn{2}{|c|}{$\begin{array}{c}\text { climate normal } \\
1961-1990\end{array}$} & \multicolumn{2}{|c|}{$\begin{array}{c}\text { mean of } \\
1987-2007 \\
\end{array}$} \\
\hline & $\begin{array}{l}\text { precipitation } \\
\mathrm{mm}\end{array}$ & $\%$ & $\begin{array}{l}\text { precipitation } \\
\mathrm{mm}\end{array}$ & $\%$ & $\begin{array}{l}\text { Precipitation } \\
\mathrm{mm}\end{array}$ & $\%$ & $\begin{array}{c}\text { Precipitation } \\
\mathrm{mm}\end{array}$ & $\%$ \\
\hline Spring (03 05) & 142 & 21.3 & 139 & 20.6 & 149 & 21.4 & 119.5 & 20.3 \\
\hline Summer (06 08) & 231 & 34.6 & 233 & 34.5 & 254 & 36.5 & 204.1 & 34.6 \\
\hline Autumn (09 11) & 174 & 26.0 & 164 & 24.2 & 162 & 23.3 & 144.5 & 24.5 \\
\hline Winter (12 02) & 121 & 18.1 & 140 & 20.7 & 131 & 18.8 & 121.3 & 20.6 \\
\hline Mean of year & 668 & 100 & 676 & 100 & 696 & 100 & 589.4 & 100.0 \\
\hline
\end{tabular}

The trends noted in the changes of the precipitation amounts and distribution according to the season could precondition the increased intensity of infiltration in southeastern Lithuania. However, other researchers state that only in autumn the rainfall amount has a more pronounced impact on a runoff into large rivers of Lithuania, while during other periods the correlation between the precipitation amount and runoff volume is weak (Bagdžiūnaitè-Litvinaitienè, Litvinaitis, 2009). According to Šileika and Gaigalis (2007) precipitation has the greatest influence on water quality in the streams of southeast Lithuania compared with other environmental factors $\left(R^{2}=0.61\right)$

On the territory of Belarus, precipitation amount decreased throughout all seasons: in spring by $29 \mathrm{~mm}$, in summer by $50 \mathrm{~mm}$, in autumn by $17 \mathrm{~mm}$ and in winter by $10 \mathrm{~mm}$. However, the precipitation ratio of separate seasons changed slightly. Compared with Lithuania, in Belarus the precipitation amount during separate seasons was by 19-29 mm lower.

Precipitation infiltration. Regarding the climate and soil conditions of Lithuania, an average of $36-53 \%$ of precipitation percolate through the soil; in sandy soils the infiltration is more intense, in limnoglacial clay soils it is weaker. In sandy loam soils about $43 \%$ of precipitation is filtered (Tyla et al., 1997). Precipitation infiltration depends not only on its amount but also on the intensity, temperature regime, evaporation conditions, vegetative cover (Frei et al., 1998; Mclsaac, 2012). According to the data averaged over 1987-2008 in the study site in Vilnius the annual average infiltration made up $310 \mathrm{~L} \mathrm{~m}^{-2}$ of precipitation or $44.9 \%$ of the annual precipitation amount (Table 2). Depending on the hydrothermal conditions of a particular year, the infiltration rate ranged from $101.8 \mathrm{~L} \mathrm{~m}^{-2}$ in 1991 to $455.1 \mathrm{~L} \mathrm{~m}^{-2}$ in 2006 , so it differed more than four times.

In Belarus, Minsk, in analogous soil the infiltration made up 38.4-40.3\% of the annual precipitation (Table 3). More intense precipitation infiltration took place in spring and made $46-48 \%$ of the total infiltration volume. At the beginning of the $21^{\text {st }}$ century precipitation infiltration in soils decreased significantly and amounted to only $12.5 \%$ in loam soils and $30.2 \%$ in sandy loam soils (Сазоненко, Пироговская, 2006).

The correlation analysis of precipitation and leachate volume showed that in East Lithuania the precipitation amount and intensity accounted for only $57 \%$ of the infiltrated precipitation, while the other part depended on temperature regime, evaporation conditions, vegetation cover, etc. Stronger correlation between 
Table 2. Changes in precipitation infiltration in facility sites in Lithuania during March 1987 - February 2008

\begin{tabular}{|c|c|c|c|c|c|c|c|}
\hline \multirow{3}{*}{ Season } & \multirow{3}{*}{ Month } & \multicolumn{6}{|c|}{ Periods } \\
\hline & & \multicolumn{2}{|c|}{03 1987-02 2008} & \multicolumn{2}{|c|}{03 1987-02 1991} & \multicolumn{2}{|c|}{03 2003-02 2008} \\
\hline & & $\mathrm{L} \mathrm{m}^{-2}$ & $\mathrm{CV}$ & $\mathrm{L} \mathrm{m}^{-2}$ & $\mathrm{CV}$ & $\mathrm{L} \mathrm{m}^{-2}$ & $\mathrm{CV}$ \\
\hline \multirow[t]{4}{*}{ Spring } & 03 & 44.2 & 0.90 & 30.3 & 0.73 & 52.4 & 0.92 \\
\hline & 04 & 48.9 & 0.91 & 53.1 & 2.01 & 60.3 & 0.90 \\
\hline & 05 & 9.6 & 1.88 & 1.2 & 1.67 & 19.6 & 1.74 \\
\hline & $\sum$ & 102.7 & 0.40 & 84.6 & 0.88 & 132.3 & 0.35 \\
\hline \multirow[t]{4}{*}{ Summer } & 06 & 5.8 & 2.57 & 16.1 & 6.69 & 5.3 & 1.13 \\
\hline & 07 & 16.6 & 1.66 & 18.9 & 1.67 & 16.8 & 1.74 \\
\hline & 08 & 15.2 & 1.96 & 14.9 & 1.13 & 34.4 & 1.19 \\
\hline & $\sum$ & 37.6 & 1.10 & 49.9 & 1.11 & 56.5 & 0.74 \\
\hline \multirow[t]{4}{*}{ Autumn } & 09 & 14.1 & 1.77 & 22.9 & 1.41 & 11.1 & 1.80 \\
\hline & 10 & 28.6 & 1.03 & 14.6 & 1.09 & 23.3 & 1.04 \\
\hline & 11 & 29.2 & 0.72 & 33.6 & 1.05 & 31.6 & 0.45 \\
\hline & $\sum$ & 71.9 & 0.75 & 71.1 & 1.07 & 66.0 & 0.74 \\
\hline \multirow[t]{4}{*}{ Winter } & 12 & 29.2 & $0, .86$ & 25.7 & 1.14 & 48.3 & 0.48 \\
\hline & 01 & 35.4 & 0.96 & 47.8 & 0.31 & 28.3 & 0.89 \\
\hline & 02 & 33.3 & 1.26 & 21.3 & 1.01 & 11.1 & 1.88 \\
\hline & $\sum$ & 97.9 & 0.75 & 94.8 & 0.48 & 87.7 & 0.45 \\
\hline Mean of year & & 310.1 & 0.32 & 300.4 & 0.48 & 342.5 & 0.18 \\
\hline
\end{tabular}

$\mathrm{CV}$ - coefficient of variation

Table 3. Changes in precipitation infiltration in facility sites in Belarus during March 1987 - February 2008

\begin{tabular}{|c|c|c|c|c|c|c|c|}
\hline \multirow{3}{*}{ Season of year } & \multirow{3}{*}{ Month } & \multicolumn{6}{|c|}{ Periods } \\
\hline & & \multicolumn{2}{|c|}{03 1987-02 2008} & \multicolumn{2}{|c|}{03 1987-02 1991} & \multicolumn{2}{|c|}{03 2003-02 2008} \\
\hline & & $\mathrm{L} \mathrm{m}^{-2}$ & $\mathrm{CV}$ & $\mathrm{L} \mathrm{m}^{-2}$ & $\mathrm{CV}$ & $\mathrm{L} \mathrm{m}^{-2}$ & $\mathrm{CV}$ \\
\hline \multirow[t]{4}{*}{ Spring } & 03 & 47.7 & 0.77 & 16.4 & 1.20 & 29.1 & 1.04 \\
\hline & 04 & 56.1 & 0.76 & 37.1 & 0.72 & 45.6 & 0.81 \\
\hline & 05 & 10.9 & 0.32 & 3.5 & 1.42 & 14.7 & 1.22 \\
\hline & $\sum$ & 114.7 & 0.34 & 57.0 & 0.25 & 89.4 & 0.21 \\
\hline \multirow[t]{4}{*}{ Summer } & 06 & 8.3 & 0.31 & 9.6 & 1.08 & 5.6 & 1.64 \\
\hline & 07 & 6.6 & 0.32 & 3.3 & 1.65 & 2.7 & 2.24 \\
\hline & 08 & 5.9 & 0.22 & 1.4 & 2.24 & 2.7 & 2.24 \\
\hline & $\sum$ & 20.8 & 1.09 & 14.3 & 1.03 & 11.0 & 0.95 \\
\hline \multirow[t]{4}{*}{ Autumn } & 09 & 7.0 & 0.31 & 5.5 & 2.24 & 10.1 & 1.52 \\
\hline & 10 & 12.8 & 0.40 & 8.1 & 1.10 & 8.6 & 0.88 \\
\hline & 11 & 15.8 & 0.33 & 12.3 & 1.07 & 6.8 & 1.41 \\
\hline & $\sum$ & 35.6 & 1.17 & 25.9 & 1.26 & 25.5 & 1.15 \\
\hline \multirow[t]{4}{*}{ Winter } & 12 & 17.7 & 0.36 & 13.0 & 1.10 & 15.1 & 0.81 \\
\hline & 01 & 29.3 & 0.56 & 22.0 & 0.87 & 24.6 & 0.94 \\
\hline & 02 & 19.3 & 0.46 & 12.3 & 1.20 & 12.3 & 1.20 \\
\hline & $\sum$ & 66.3 & 0.66 & 47.3 & 0.68 & 52.0 & 0.60 \\
\hline Mean of year & & 237.4 & 0.35 & 144.5 & 0.22 & 177.9 & 0.35 \\
\hline
\end{tabular}

$\mathrm{CV}$ - coefficient of variation

precipitation and leachate volume was established during summer $\left(R^{2}=0.77, \mathrm{t}_{\mathrm{r}}=99.9 \%\right)$ and autumn $\left(R^{2}=0.48, \mathrm{t}_{\mathrm{r}}=\right.$ $99.9 \%$ ) periods (Fig. 2). It should be noted that in summer the infiltration intensity increases only if the rainfall amount exceeds $250 \mathrm{~mm}$, because more intense moisture evaporation occurs during this period as compared to other seasons, and part of moisture is used by plants. In winter, the correlation is weaker $\left(R^{2}=0.33\right)$, because in frozen soil infiltration ceases. In spring, infiltration can increase due to snow accumulated during winter, therefore, the correlation between precipitation and infiltrated water quantity of spring is weak $\left(R^{2}=0.13\right)$.

In Belarus (Minsk), with lower annual precipitation amount, the relationship of infiltration with rainfall was stronger. During 1987-2008, the average annual correlation of precipitation and infiltration volume was $R^{2}=0.752\left(\mathrm{t}_{\mathrm{r}}=99.9 \%\right)$, while seasonal distribution was the following: spring $-R^{2}=0.978\left(\mathrm{t}_{\mathrm{r}}=\right.$
$99.9 \%)$, summer $-R^{2}=0.537\left(\mathrm{t}_{\mathrm{r}}=99.9 \%\right)$, autumn $0.120\left(\mathrm{t}_{\mathrm{r}}=92.8 \%\right)$, winter $-0.592\left(\mathrm{t}_{\mathrm{r}}=99.9 \%\right)$.

Winter season. Lithuanian climate is characterized by frequent winter thaws, and during 1991-2003 the average temperature of the season compared to climate normal (1961-1990) in Vilnius increased by $1.3^{\circ} \mathrm{C}$ (Galvonaitè et al., 2007). This creates favourable conditions for precipitation infiltration, and consequently, leaching of chemical elements from humus layer. During winter in eastern Lithuania, the average infiltration volume reaches $98.2 \mathrm{~L} \mathrm{~m}^{-2}$ accounting for $31.6 \%$ of the annual infiltration volume (Table 2$)$. In separate years (10\% probability), because of low temperature, infiltration may not occur, and there is a $63 \%$ probability that it may exceed average values. Comparison of the infiltration intensity of the two study periods (1987-1991 and 2003-2008) indicates that during the latter period infiltration slightly declined $(7.5 \%)$, besides the distribution of infiltrated 

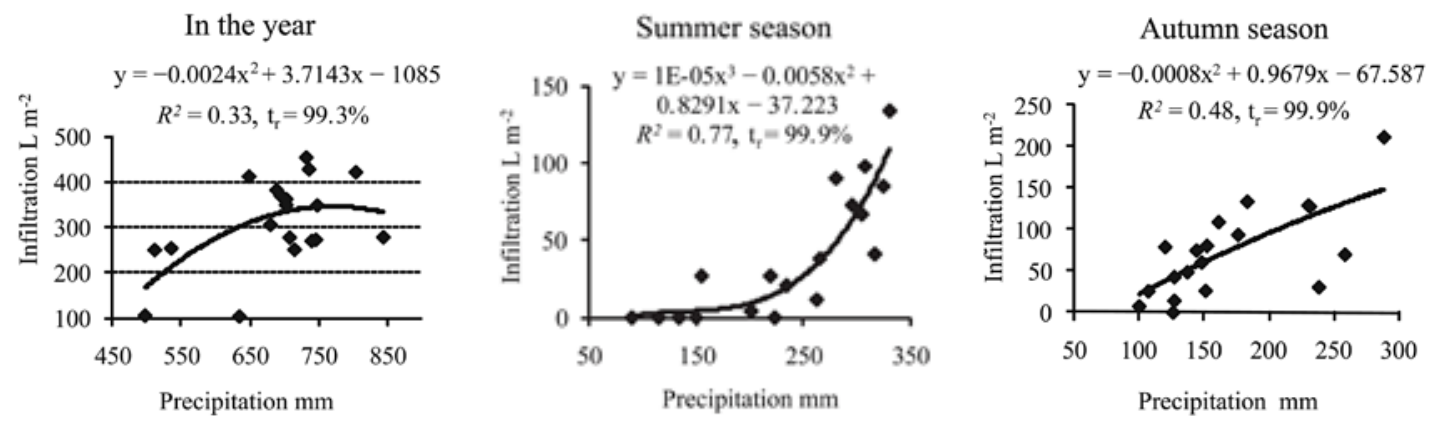

Figure 2. The relationship between precipitation amount and infiltration in the year and at different seasons in Lithuania

water volume by month changed. Compared with the average of the whole studied period (1987-2008), due to climate change, over the 2003-2008 period precipitation infiltration in December increased by $65.2 \%$ and decreased in January and February (20.0 and $26.5 \%$, respectively). Changes in the trend of the entire winter period during 1987-2008 show only a slight increase in the infiltrated volume (Fig. 3), so it can be noted that increased average air temperature by $1.3^{\circ} \mathrm{C}$ and precipitation by $2.6 \%$ in winter basically did not intensify the infiltration.
In Belarus (Minsk), the patterns of precipitation infiltration distribution by the periods of a year were similar to those in Lithuania (Table 2). Judging by the data of 1987-2008, increased precipitation infiltration occurred in spring $\left(114.7 \mathrm{~L} \mathrm{~m}^{-2}\right)$ and winter $\left(66.3 \mathrm{~L} \mathrm{~m}^{-2}\right)$. In Lithuania, during winter infiltration was only by $4.4 \%$ lower than in spring, meanwhile in Belarus this difference made up $42.2 \%$, which is related to lower average temperature in winter.

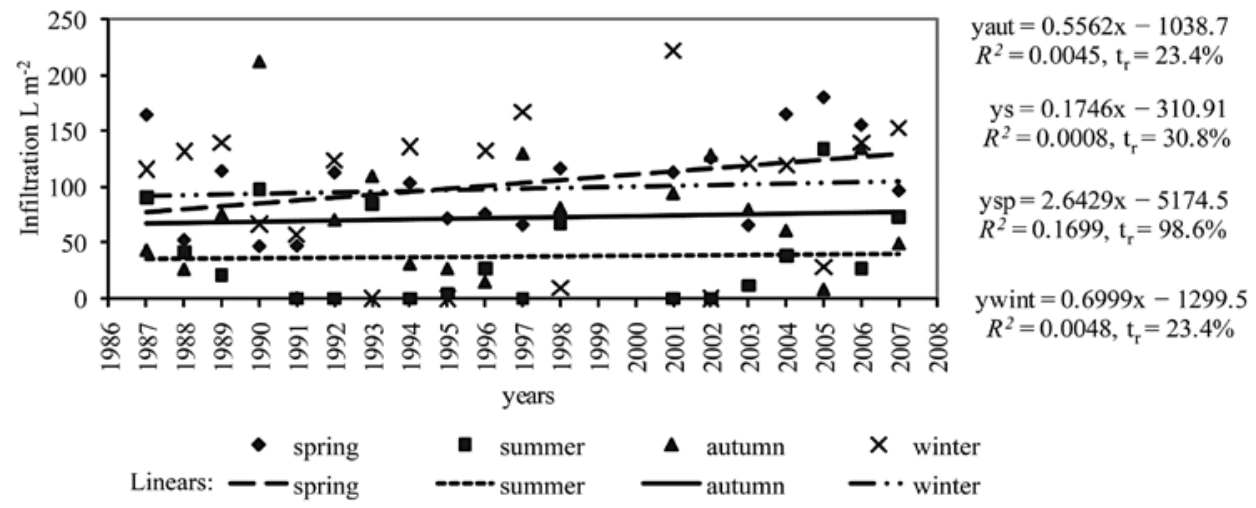

Figure 3. Trends in the changes of precipitation infiltration in the facility site in Lithuania (Vilnius) during March 1987 - February 2008

The data averaged over 1987-2008 show that in Belarus $27.9 \%$ of the annual precipitation infiltrates in winter. Over the past two decades, compared with the climate normal, precipitation amount in the winter period decreased by only $10 \mathrm{~mm}$, and the air temperature increased by $-3.6^{\circ} \mathrm{C}$ (climate normal $-5.8^{\circ} \mathrm{C}$ ) (Метеорологические ежемесячники 1987-2007г.). Precipitation infiltration trend of the winter season shows a slight decrease in infiltration. However, when comparing data of 1987-1991 and 2003-2008, it could be noted that over the last analyzed five years precipitation infiltration was by $9.9 \%$ higher. This can be related to higher temperature in December; in 2003-2008 average air temperature was only $-0.6^{\circ} \mathrm{C}$ (in $1987-1991$ it was $-3.0^{\circ} \mathrm{C}$ ) and such conditions were more favourable for precipitation percolation.

Spring season. In Lithuania, the highest amount (102.7 $\mathrm{L} \mathrm{m}^{-2}$ or $33.1 \%$ of the annual infiltrate volume) of rainfall is filtered through the soil during spring. Spring months can strongly differ according to the infiltrated water volume. For example, during the study period, the low temperature in March withheld the infiltration until April four times; three times due to low precipitation amount it was withheld in April, and six times no infiltration was registered in May. But the average data of the years 1987-2008 show infiltration in March and April to be quite similar, making 44.2 and $48.9 \mathrm{~L} \mathrm{~m}^{-2}$, respectively. Still in May, with increasing moisture evaporation from the soil surface and its use by plants, infiltration reduced by about four times (to $9.6 \mathrm{~L} \mathrm{~m}^{-2}$ ). Regression equation of infiltration changes shows that over the past two decades infiltration tended to increase in March $\left(\mathrm{y}_{\text {March }}=2.21 \mathrm{x}+\right.$ $\left.22.11, R^{2}=0.098\right)$ and May $\left(\mathrm{y}_{\text {May }}=0.977 \mathrm{x}-0.219, R^{2}=\right.$ 0.094), but according to the correlation coefficient values the changes are insignificant. Comparison of the data of the two studied periods shows that in 2003-2008 water infiltration in spring substantially increased. Compared to 1987-2008, infiltration increased by $29.6 \mathrm{~L} \mathrm{~m}^{-2}$ or $28.8 \%$, compared to $1987-1991$ - even by $47.6 \mathrm{~L} \mathrm{~m}^{-2}$ or $56.2 \%$. Therefore, the rise of spring air temperature by $0.9^{\circ} \mathrm{C}$ (Galvonaite et al., 2007) over the past two decades and higher amount of precipitation in 2003-2008 intensified the precipitation infiltration in spring.

Under climatic conditions of Belarus the strongest precipitation infiltration $\left(114.7 \mathrm{~L} \mathrm{~m}^{-2}\right.$ or $48.3 \%$ of the annual amount) was also observed in spring. 


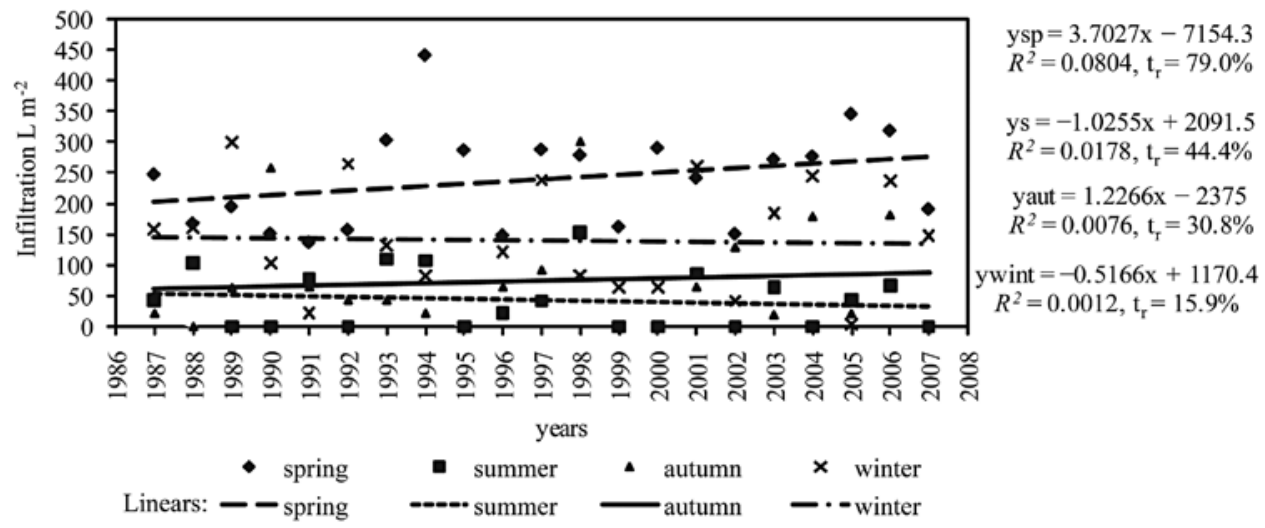

Figure 4. Trends in the changes of precipitation infiltration in the facility site in Belarus (Minsk) during March 1987 - February 2008

Likewise in Lithuania, in March and April the infiltration volume was quite similar averaging 47.7 and $56.1 \mathrm{~L} \mathrm{~m}^{-2}$; in May infiltration volume decreased and was similar $\left(10.9 \mathrm{~L} \mathrm{~m}^{-2}\right)$ to that in Lithuania. The analysis of the changes during the studied period reveals that, compared to 1987-2008 average, over the 2003-2008 period infiltration in spring increased by $16.9 \%$, and compared to $1987-1991$ period - by $56.7 \%$. Significant infiltration increase compared to $1987-1991$ period was due to higher precipitation in spring $(+34.7 \%)$ and especially higher amount of rainfall in May. Correlation analysis of infiltration of separate spring months showed that during the last two decades the intensity of infiltration increased in March. Likewise in Lithuania, climate warming increased the spring precipitation infiltration on the territory of Belarus (Minsk).

Summer season in Lithuania is rather rainy $68-87 \mathrm{~mm}$ of rainfall per month. Still the infiltration in summer is negligible; according to the data of 1987-2008 the average infiltration in summer made up $37.6 \mathrm{Lm}^{-2}$ or $12.1 \%$ of the annual infiltrated volume. Most frequently ( $74 \%$ probability) the infiltration ceases in June resulting from the intensive use of water by plants and hydrothermal regime. In July, with increasing rainfall amount the infiltration could resume ( $42 \%$ probability), the same probability exists for August. Trends of infiltration changes in 1987-2008 indicate that in the facility site in Lithuania (Vilnius) rainfall infiltration increased in August $\left(\mathrm{y}_{\text {August }}\right.$ $\left.=1.32 \mathrm{x}+2.038, R^{2}=0.062, \mathrm{t}_{\mathrm{r}}=71.5 \%\right)$, and slightly decreased in June and July $\left(\mathrm{y}_{\mathrm{Iune}}=-0.91 \mathrm{x}+14.88, R^{2}=\right.$ $0.118, \mathrm{t}_{\mathrm{r}}=87.5 \% ; \mathrm{y}_{\text {July }}=-0.247 \mathrm{x}+19.07, R^{2}=0.0026$, $\mathrm{t}_{\mathrm{r}}=51.0 \%$ ). Due to climate conditions variation, the correlation coefficients are insignificant, so the changes can be regarded as trends formed during a 20-year period.

In Belarus (Minsk), rainfall infiltration in summer made up an average of $20.8 \mathrm{~L} \mathrm{~m}^{-2}(8.8 \%$ of the annual infiltration amount). Trends of infiltration changes during 1987-2008 show a slight increase in June $\left(\mathrm{y}_{\text {June }}=\right.$ $\left.1.016 \mathrm{x}+28.57, R^{2}=0.041\right)$ and August $\left(\mathrm{y}_{\text {August }}=0.533 \mathrm{x}\right.$ $+6.51, R^{2}=0.022$ ). Due to the variation of climatic conditions, the correlation was insignificant. It should be mentioned that in 2003-2008 infiltration declined to $5.7-5.6 \mathrm{~L} \mathrm{~m}^{-2}$ and such amount of infiltrate, regardless of the concentrations of chemical elements in it, could not produce a substantial adverse effect on surface water quality. Comparison of the data from both facility sites revealed common tendency of the increased infiltration in August when the crop yield is removed.
Autumn season. During this period, on the territory of Lithuanian, decreasing temperature resulted in reduced moisture evaporation from the soil surface and its use by plants. This created favourable conditions for rainfall infiltration. According to the data averaged over 1987-2008, in the facility site in Lithuania (Vilnius) $71.9 \mathrm{~L} \mathrm{~m}^{-2}$ of precipitation or $13.2 \%$ of the annual volume infiltrated in autumn. Very rarely (5\% probability) the autumn happens to be dry and no infiltration is observed; there is a $26-36 \%$ probability that there will be no infiltration during one of the autumn months. Over the past twenty years, infiltration changes in autumn were not significant $\left(\mathrm{y}_{\text {aut }}=0.556 \mathrm{x}-1038.7, R^{2}=0.0045, \mathrm{t}_{\mathrm{r}}=\right.$ 23.4\%). The correlation analysis of infiltration changes during autumn months showed the increased infiltration in October $\left(\mathrm{y}_{\text {october }}=1.320 \mathrm{x}+15.36, R^{2}=0.064, \mathrm{t}_{\mathrm{r}}=71.5 \%\right)$ and decreased in September $\left(\mathrm{y}_{\text {September }}=-0.734 \mathrm{x}+21.46\right.$, $\left.R^{2}=0.027, \mathrm{t}_{\mathrm{r}}=51.0 \%\right)$ and November $\left(\mathrm{y}_{\text {November }}=-0.016 \mathrm{x}\right.$ $\left.+29.41, R^{2}=2 \mathrm{E}-05, \mathrm{t}_{\mathrm{r}}=\%\right)$. Due to the variation of climatic condition, the correlation was insignificant. It could be noted that, compared to the 1987-2008 data, during the last period (2003-2008) precipitation decreased by $8.3 \%$ in autumn, while compared with the climate normal - by $26.1 \%$. With decreasing precipitation, reduced infiltration during this period could be observed. In the future, this could have a positive impact on the reduction of surface water pollution from agricultural land.

In Belarus, likewise in Lithuania, we can see a similar downward trend in precipitation amount in autumn. Compared with the climate normal, precipitation amount decreased by $17.5 \mathrm{~mm}$ or $10.8 \%$ and this inevitably affected infiltration. In 2003-2008, compared to the data of 1987-2008, autumn infiltration decreased by $10.1 \mathrm{~L} \mathrm{~m}^{-2}$ or $28.4 \%$. Infiltration volume by month also changed. Compared to 1987-2008 average, during the recent period increased precipitation infiltration occurred in September, while a decrease was observed in October and November.

Generalization. The Nemunas River Basin covers part of the territory of western Belarus and southeastern Lithuania and the agricultural activities performed in the region influence the condition of water bodies. In most cases, the effect of mineral and organic fertilizers and pesticides used in agriculture to increase crop yield is negative, because under the impact of precipitation some organic compounds, nutrients are leached into the subsoil layers and get into the drainage and surface waters. Assessment of the Nemunas River Basin suggests that due to the impact of agricultural activities, approximately $2136 \mathrm{~km}$ of rivers and 24 lakes do 
not satisfy the requirements of good ecological condition. Thus, agricultural activities are identified among the factors most significantly affecting the quality (Paukštys, 2011).

Precipitation infiltration intensity and the associated extent of pollution are strongly influenced by precipitation amount, its distribution throughout the year and temperature regime. Over the past two decades (1987-2007), in Belarus and Lithuania changes in precipitation amount were opposite. In 1987-2007 in eastern Lithuania (Vilnius), the average annual precipitation slightly increased $(+8 \mathrm{~mm})$ compared to the climate normal (1961-1990), meanwhile in Belarus (Minsk), at the locality situated $200 \mathrm{~km}$ to the south-east, it noticeably decreased $(-106.6 \mathrm{~mm})$. The precipitation amount more substantially decreased in summer $(19.6 \%)$ and spring (19.8\%) periods. According to Kriauciuniene et al. (2010), an upward trend in precipitation amount during 1991-2007, compared to 1961-1990, was recorded in most of the Baltic countries except for Estonia, where changes in the trend were slightly negative. Over the last two decades throughout the Baltic States the air temperature increase was also recorded (Kriauciuniene et al., 2010). Similar changes were determined in both Lithuania and Belarus. In Lithuania, annual temperature increased by $0.1-0.9^{\circ} \mathrm{C}$ and in Belarus by $1.0-2.0^{\circ} \mathrm{C}$ (Galvonaitè et al., 2007; Логинов, 2008).

Changes of climate indices in both countries affected the precipitation infiltration. Compared to 1987-2008, during 2003-2008 in Lithuania the annual average infiltration increased by $10.3 \%\left(32.0 \mathrm{~L} \mathrm{~m}^{-2}\right)$. Very significant change occurred in summer - the infiltration increased by $50.2 \%$, although rainfall amount remained almost unchanged. The increased infiltration was associated with rainfall intensity, when large amount fell over a short period of time. After simulation trials, Marcinkonis and Bukantis (2011) stated that over intense rain, during 700 hours in sandy loam soil the infiltration volume may reach $76.7-81.6 \mathrm{~mm}$. According to climate change scenarios ECHAM5 B1 and HadCM3 A1B, till the year 2020, in eastern Lithuania an increase in river discharge during summer periods is predicted (Paukštys, 2011) and this prediction correlates with the observation data on increased infiltration over separate summer months. Increased infiltration $\left(+28.8 \%\right.$ or $\left.+29.6 \mathrm{~L} \mathrm{~m}^{-2}\right)$ was also recorded in March and May. Increased infiltration in May, right after the spring time application of fertilizers on agricultural land, can increase the migration of chemical elements, but considering the infiltration volume (average of $9.6 \mathrm{~L} \mathrm{~m}^{-2}$ per month) it should not adversely affect groundwater quality.

In Belarus (Minsk), during 1987-2007 precipitation amount substantially reduced resulting in decreased annual infiltration. During 2003-2008 compared with the data of 1987-2008 it decreased by on average $25.1 \%$ $\left(-59.5 \mathrm{~L} \mathrm{~m}^{-2}\right)$. In contrast to Lithuania, infiltration decreased most considerably $(-53.4 \%)$ in summer, while during other seasons the relative reduction was quite similar - 21.6-28.4\%. It can be expected that significant decrease in infiltration will reduce the pollution load of river basins with biogenic elements. This assumption is supported by water studies of the Nemunas and Neris rivers performed in 2008 at the Belarusian border. It was found that in water flow coming from Belarus nitrogen and phosphorus concentrations were $1.16-0.75 \mathrm{mg}$ $\mathrm{NO}_{3}-\mathrm{N} \mathrm{L}^{-1}$ and $0.09 \mathrm{mg} \mathrm{P} \mathrm{L}^{-1}$, respectively, and they did not exceed the limit values for good ecological status (Paukštys, 2011).

\section{Conclusions}

1. During the analyzed period (1987-2007), on the studied territory of Lithuania(Vilnius) the precipitation amount slightly increased $(13 \mathrm{~mm})$, compared to the climate normal (1961-1990), the variation in separate years ranged from -33.5 to $+10.3 \%$. In Belarus (Minsk), $200 \mathrm{~km}$ in south-east direction away from Vilnius during 1987-2007 the precipitation amount decreased by 109 $\mathrm{mm}$ compared with the climate normal $(696 \mathrm{~mm})$; a greater decrease was observed in summer $(50 \mathrm{~mm})$.

2. During March 1987 - February 2008 in Lithuania (Vilnius), in sandy loam soils annual average infiltration reached $44.9 \%(\mathrm{CV}=0.32)$, in Belarus (Minsk) $-40.3 \%(\mathrm{CV}=0.35)$ of annual precipitation amount. In both countries increased infiltration occurred during spring $-32.2 \%$ of the annual precipitation amount in Lithuania and $48.3 \%$ in Belarus. Minimum infiltration took place during summer $-12.1 \%$ and $8.9 \%$ of the annual precipitation amount, respectively.

3. In Lithuania, precipitation infiltration rate mostly varied $(\mathrm{CV}=1.66-2.57)$ during the summer months, in Belarus - during spring months $(\mathrm{CV}=0.32$ 0.77). During 1987-2008, infiltration variation in separate months in Belarus was lower than in Lithuania, but in the 2003-2008 period the differences of infiltration in the summer period $(\mathrm{CV}=1.64-2.24)$ significantly increased.

4. In the period of March 1987 - February 2008 in Lithuania, a significant increase in the infiltration of atmospheric precipitation during the spring period was established. The tendency of an increase in the infiltration during the summer period and reduction during the autumn period was also noted (correlations insignificant). In the Republic of Belarus, with a considerable reduction of precipitation amount its infiltration in the soil decreased; however, because of the variation of climatic conditions, statistically significant trends of changes of infiltration were not established.

\section{Acknowledgements}

The paper presents research findings, obtained through the long-term research programme "Productivity and sustainability of agricultural and forest soils" implemented by Lithuanian Research Centre for Agriculture and Forestry and the research programmes "Agrocomplex - Rural Revival and Development", "Agrocomplex - Sustainable Development" and the National Applied Research Program "Create agricultural land use efficiency and soil fertility enhancement tools available for investigation of its composition, properties and ecological status" (Agriculture and machinery).

Received 29112012 Accepted 23092013

\section{References}

Adomaitis T., Mažvila J., Vaišvila Z., Arbačiauskas J., Antanaitis A., Lubyte J., Šumskis D. 2010. The effect of long-term fertilisation on anion leaching. Zemdirbyste-Agriculture, 97 (1): 71-82 (in Lithuanian)

Bagdžiūnaitè-Litvinaitienè L., Litvinaitis A. 2009. Flow change regularities in Lithuanian rivers of different size. Vandens ūkio inžinerija, 36 (56): 74-81 (in Lithuanian)

Baigys G. 2009. The influence of reduced soil tillage on drainage runoff and leaching of phosphates. Vandens ūkio inžinerija, 36 (56): 33-40 (in Lithuanian) 
Bukantis A., Gulbinas Z., Kazakevicius S., Kilkus K., Mikelinskiene A., Morkunaite R., Rimkus E., Samuila M., Stankunavicius G., Valiuskevicius G., Zaromskis R., 2001. The influence of climatic variations on physical geographical processes in Lithuania. Institute of Geography and Vilnius University, 280 p. (in Lithuanian)

Frei Ch., Schar Ch., Luthi D., Davies H. C. 1998. Heavy precipitation processes in a warmer climate. Geophysical Research Letters, 25 (9): 1431-1434 http://dx.doi.org/10.1029/98GL51099

Galvonaite A., Valiukas D. 2005. Some indicators of climatic changes during the last decade in Lithuania. Meteorology and hydrology in Lithuania: evolution and prospects: scientific conference. Vilnius, p. 31-32 (in Lithuanian)

Galvonaite A., Misiūnienė M., Valiukas D., Buitkuvienė M. S. 2007. Lithuanian climate. Vilnius, 207 p. (in Lithuanian)

Kaczmarek Z. 1993. Water balance model for climate impact analysis. ACTA Geophysica Polonica, 41 (4): 1-16

Kilkus K., Štaras E., Rimkus E., Valiuškevičius G. 2006. Changes in water balance structure of Lithuanian rivers under different climate change scenarios. Aplinkos tyrimai, inžinerija ir vadyba, 36 (2): 3-10

Kriauciuniene J., Reihan A., Kolcova T., MeilutyteBarauskiene D., Lizuma L. 2010. Regional temperature, precipitation and runoff series in the Baltic countries. Conference on Future Climate and Renewable Energy: Impacts, Risks and Adaptation. Oslo, Norway, p. 14-16

Kutilek M., Nielsen D. R. 2010. Facts about global warming. Reiskirchen, Germany, 227 p.

Kutra G., Gaigalis K., Šmitienè A. 2006. Land use influence on nitrogen leaching and options for pollution mitigation. Zemdirbyste-Agriculture, 93 (4): 119-129

Marcinkonis S., Bukantis A. 2011. Assesing the risk of carbon and nitrogen leaching during extreme rainfalls: climate change: agro- and forest systems sustainability. Abstract of international scientific conference. Lithuanian Institute of Horticulture, p. 26-27
Mclsaac G. 2012. Agricultural nutrient management in the Great Lakes region. Jakobsson Ch. (ed.) Sustainable Agriculture. Uppsala University, Sweden, p. 102-106

Meissner R., Rupp H., Seeger J. Seyfarth M. 2006. Innovation in lysimeter techniques. $18^{\text {th }}$ World Congress of Soil Science. Philadelphia, USA

Meissner R., Rupp H., Seeger J., Ollesch G., Gee G. W. 2010. A comparison of water flux measurements: passive wicksamplers versus drainage lysimeters. European Journal of Soil Science. 61: 609-621 http://dx.doi.org/10.1111/j.1365-2389.2010.01255.x

Paukštys B. 2011. Lietuvos vandens telkinių būklè ir ūkinès veiklos poveikis. Vilnius, 632 p. (in Lithuanian)

Schoumans O. P., Groenendijk P. 2000. Modeling soil phosphorus levels and phosphorus leaching from agricultural land in the Netherlands. Journal of Environmental Ouality, 29: 111-116 http://dx.doi.org/10.2134/jeq2000.00472425002900010014x

Strusevičius Z., Kazakevičienè J., Berankienė L. 2009. Changes in river water quality downstream from the pig complex. Vandens ūkio inžinerija, 35 (55): 42-51 (in Lithuanian)

Šileika A. S., Gaigalis K. 2007. Influence of natural and anthropogenic factors on nitrogen leaching in stream catchments. Vandens ūkio inžinerija, 31 (51): 36-46 (in Lithuanian)

Tyla A., Rimšelis J., Šleinys R. 1997. Augalų maisto medžiagu išplovimas iš įvairių dirvožemių. Vilnius, 26 p. (in Lithuanian)

Климат Беларуси. 1996. Логинов В. Ф. (ред.). Минск, 360 с. (in Russian)

Логинов В. Ф. 2008. Глобальные и региональные изменения климата: причины и следствия. Минск, 495 с. (in Russian)

Метеорологические ежемесячники 1987-2007 г. Минск (in Russian)

Сазоненко О. П., Пироговская Г.В.2006. Состав и поступление химических веществ в почву с атмосферными осадками. Почвоведение и агрохимия, 1 (36): 89-100 (in Russian)

ISSN 1392-3196 / e-ISSN 2335-8947

Zemdirbyste-Agriculture, vol. 100, No. 4 (2013), p. 369-376

DOI $10.13080 /$ z-a.2013.100.047

\title{
Klimato veiksnių varijavimo Lietuvoje ir Baltarusijoje įtaka atmosferos kritulių infiltracijai: lizimetrinis tyrimas
}

\author{
L. Tripolskaja ${ }^{1}$, G. Pirogovskaja ${ }^{2}$ \\ ${ }^{1}$ Lietuvos agrarinių ir miškų mokslų centro Vokès filialas \\ ${ }^{2}$ Baltarusijos dirvotyros ir agrochemijos institutas
}

\section{Santrauka}

Lietuvos ir Baltarusijos teritorijose atmosferos kritulių filtracija sudaro apie 38-40 \%. Žemès ūkio naudmenose kartu su filtraciniu vandeniu ị podirvị išplaunama nemažai biogeninių elementų, kurie gali turèti neigiamos įtakos vandens telkinių kokybei. Tyrimo tikslas - ivvertinti klimato veiksnių variacijos įtaką atmosferos kritulių infiltracijai Lietuvos (Vilniaus) ir Baltarusijos (Minsko) teritorijose. Panaudoti $1987 \mathrm{~m}$. kovo - $2008 \mathrm{~m}$. vasario mènesių stacionarių lizimetrinių (lizimetrų paviršiaus plotas - 1,75-2,0 $\mathrm{m}^{-2}$ ) eksperimentų kritulių infiltracijos duomenys. Nustatyta, kad 1987-2007 m. laikotarpiu kritulių kiekis tiriamoje vietovejje Lietuvoje (Vilniuje), palyginus su klimato norma, nežymiai padidejo $(+10 \mathrm{~mm})$, o Baltarusijoje (Minske) žymiai sumažèjo $(-109 \mathrm{~mm})$, pakito jų kiekis tam tikrais menesiais, ir tai turejo itakos kritulių infiltracijos dydžiui. Lietuvoje kritulių ir infiltracinio vandens kiekio stiprus koreliacinis ryšys nustatytas vasaros $\left(R^{2}=0,77, \mathrm{t}_{\mathrm{r}}=99,9 \%\right)$, vidutinio stiprumo - rudens $\left(R^{2}=0,48, \mathrm{t}_{\mathrm{r}}=99,9 \%\right)$ laikotarpiais. Baltarusijoje stiprus koreliacinis ryšys nustatytas pavasarị $\left(R^{2}=0,978, \mathrm{t}_{\mathrm{r}}=\right.$ $99,9 \%)$, vidutinio stiprumo - vasaros $\left(R^{2}=0,537, \mathrm{t}_{\mathrm{r}}=99,9 \%\right)$ ir žiemos $\left(R^{2}=0,592, \mathrm{t}_{\mathrm{r}}=99,9 \%\right)$ laikotarpiais. Lietuvoje 1987-2008 m. nustatytas esminis $(p<0,05)$ atmosferos kritulių infiltracijos didejimo trendas pavasario laikotarpiu. Taip pat nustatyta infiltracijos didejjimo tendencija vasaros ir mažejjimo - rudens laikotarpiu (koreliacija neesminè). Baltarusijoje (Minske), 1987-2007 m. esmingai sumažèjus kritulių kiekiui, infiltracijos apimtis sumažèjo visais metų laikotarpiais. Tačiau dèl klimato sąlygų varijavimo esminių $(p>0,05)$ filtracijos pokyčių trendų nenustatyta.

Reikšminiai žodžiai: klimatas, kritulių infiltracija, lizimetrai, metų laikotarpiai. 